\title{
Correlation between school dropout and gross domestic product in the emerging countries of Central and Eastern Europe
}

Vodă Ioana-Maria 


\title{
Correlation between school dropout and gross domestic product in the emerging countries of Central and Eastern Europe
}

\author{
Vodă Ioana-Maria ${ }^{\text {a* }}$ \\ a"Lucian Blaga" University of Sibiu, Victoria Boulevard, Sibiu 550024, Romania \\ *Corresponding author: ioana_v94@yahoo.com
}

\section{Abstract}

Keywords:

school dropout; gross

domestic product
By school dropout is meant leaving the educational system, regardless of the reached level, before obtaining a qualification or a complete proffesional training or before the end of the study cycle started (Doron \& Parot, 2006). Although there are numerous researches on school dropout, we consider that it is necessary to study the relationship it has with the level of development of a country, in order to identify new causes and possible solutions to this phenomenon. In this study we included seven emerging countries of Central and Eastern Europe: Bulgaria, Czech Republic, Poland, Romania, Slovakia, Slovenia and Hungary. Thus, we analyzed the correlation between the annual gross domestic product and the school dropout rates in the mentioned countries. The data were extracted from the European Commission's Eurostat database and entered into the SPSS and then analyzed using the Forward prospective procedure. This research revealed the existence of significant negative correlation between the level of development of a country and the school dropout rate in the countries included in the analysis, in female, but also insignificant or weakly significant correlations between the mentioned variables in males.
Zusammenfasung

Schlüsselworte:

Schulabbrecher; Bruttoinlandsprodukt
Mit Schulabbruch ist gemeint, das Bildungssystem unabhängig vom erreichten Niveau zu verlassen, bevor eine Qualifikation oder eine Berufsausbildung abgeschlossen wird oder bevor das Ende des Studienzyklus beginnt (Doron \& Parot, 2006). Obwohl im Zusammenhang mit Schulabbrüchen zahlreiche Forschungsarbeiten durchgeführt werden, halten wir es für erforderlich, die Beziehung zum Entwicklungsstand eines Landes zu untersuchen, um neue Ursachen und mögliche Lösungen für dieses Phänomen zu ermitteln. In diese Untersuchung wurden sieben Schwellenländer in Mittel- und Osteuropa einbezogen: Bulgarien, die Tschechische Republik, Polen, Rumänien, die Slowakei, Slowenien und Ungarn. Daher haben wir die Korrelation zwischen dem jährlichen Bruttoinlandsprodukt und der Abbrecherquote in den genannten Ländern analysiert. Die Daten wurden aus der Eurostat-Datenbank der Europäischen Kommission extrahiert, in das SPSS eingegeben und anschließend nach dem Forward Prospective-Verfahren analysiert. Diese Untersuchung ergab das Vorhandensein signifikanter negativer Korrelationen zwischen dem Entwicklungsstand eines Landes und der Abbrecherquote in den in die Analyse einbezogenen Ländern bei Frauen, aber auch unbedeutende oder schwach signifikante Korrelationen zwischen den genannten Variablen bei Männern.

\section{Introduction}

In the process of becoming human, in order to develop the harmonious and balanced personality of the child, there are involved, as we find in the Romanian literature, three major factors: heredity, environment and education. Cosmovici \& Iacob (1999) define the education as "a specialized activity, specifically human, that meditates and diversifies the relationship between human and his environment, favouring the development of a man through society and society through man."

Although in terms of the evolution of the individual, education represents only a third of the total of the listed factors, it cannot be put on a secondary plan, all the more removed. Given the importance of the education in the child development, sometimes presented as a guiding factor in this regard, we want to highlight some theoretical aspects related to school dropout and its effects on the development of human personality.

By school dropout is meant leaving the educational system, regardless of the reached level, before obtaining a qualification or a complete professional training or before the end of the study cycle started (Doron \& Parot, 2006). From the same bibliographic source, we can deduce two causes to which school dropout is attributes: the inability of the educational system to adapt to the requirements of 
certain categories of children; the affective and intellectual characteristics of some students; the negative, indifferent attitude of the parents towards schooling, the attitude left as a "legacy" to the children (Doron \& Parot, 2006). It is absolutely necessary to add in this list the material difficulties of a family, especially in the case of large, disorganized ore single-parent families.

School dropout is a problem that society has faced since ancient times and is not a new issue. However, it involves from all angles of analysis, a loss: from a psychological, economic, social, cultural and moral point of view, both for society and for the individual. In order for this problem to be solved, it is necessary to analyze different aspects of society that can lead to an increase in the school dropout rate.

This paper has the following structure: section two theoretical foundation, section three - research methodology, section four - empirical results, section five conclusions and discussions.

\section{Theoretical foundation}

Following the analysis of research in the literature, we found a series of information related to school dropout in Romania and other European countries.

Apostu et al. (2015) highlights, following the analysis of data on the pre-university education system in Romania, a school dropout rate in primary and secondary education in the school year 2012-2013 of 1.4\%, meaning 24.4 thousand students. Also, in this category we find differences by areas of residence and we observe a higher percentage of school dropout in rural areas, compared to urban areas. In high school the percentage of school dropout is higher, of $2.8 \%$ and the data show a higher percentage of school dropout in boys, compared to girls. In post-secondary education and foremen, in the school year 2012-2013 there was a school dropout rate of $8.9 \%$, with a higher share of the male population than female.

Andrei et al. (2011) analyzes the differences between European Union countries in terms of school dropout rates. In this paper, several factor have been identified that determine the maintenance of a high level of school dropout in some analyzed countries: the number of pupils/students that a teacher has, the share of education expenditures and the unemployment rate. The research result shows a positive correlation between the school dropout rate and the number of pupils/students per teacher and a negative correlation between the school dropout rate and the share of education expenditures.

Regarding early school leaving in the European Union, Gyonos (2011) identified a rate of $14.9 \%$ in the Union in 2008. Although there are countries below the $10 \%$ threshold proposed by the Union to be reached in 2020 (Croatia, Poland, Slovenia, the Czech Republic or
Slovakia), there are countries where this rate is well above the proposed threshold: Turkey 46.6\%, Malta 39\%, Portugal $35.4 \%$, Spain $31.9 \%$. In Romania, in 2008, the early school leaving rate was $15.9 \%$.

There is research in which we find, in addition to statistical data on dropout, some proposed solutions to reduce school dropout. Vîrlan \& Dița (2018) propose the elaboration of a psycho-socio-educational intervention program that includes a series of complex activities of training and psychological counselling and the involvement of parents in these intervention programs, in order to reduce the problem of school dropout. Following the training experiment, the authors concluded that such a program is useful and necessary to be implemented in schools in our country.

In a research (Jigău et al., 2011) that included five schools with the common feature of the high dropout rate, it was proposed, among the measures to improve school dropout, to promote a climate of support and assistance measures for those schools that face the studied phenomenon, as well as the elaboration of a course support and a training program for the persons involved in the reporting of school dropout situations.

\section{Research methodology}

\subsection{Hypothesis}

In this paper we aim to analyze the existence of a correlation between the school dropout rate by gender, and the level of development of emerging countries in Central and Eastern Europe. We assume that there is a significant negative correlation between the two variables mentioned above.

The hypothesis from which we start are the following:

1. There is a negative significant correlation between the school dropout rate for males and the level of development of emerging countries in Central and Eastern Europe.

2. There is a negative significant correlation between the school dropout rate for females and the level of development of emerging countries in Central and Eastern Europe.

\subsection{Research data and procedure}

This research used annual data, from 2002 to 2019, from seven emerging countries in Central and Eastern Europe, using as variables the school dropout rate $\mathrm{x} 1$, and the level of development of countries $\mathrm{x} 2$, expressed by gross domestic product. The data were extracted from the European Commission's Eurostat database, for the following countries: Romania, Hungary, Bulgaria, Slovakia, Slovenia, Poland and the Czech Republic. 
For the purpose of analyzing the collected data SPSS was used. In order to highlight the existence of a relationship between the two mentioned variables, we will use the simple Pearson correlation coefficient (R) between the two variable. Data analysis using the Pearson correlation coefficient assumes the existence of a relationship between two variables, in a straight line. It is used when we want to find out to what extent two given variables are associated, if there are relationships between them (Howitt \& Cramer, 2010). The value of Pearson coefficient can vary between +1 (positive correlation), and -1 (negative correlation), and the value 0 implies the absence of a correlation between the values of the entered variables (Vasile, 2014).To avoid the tendency of $\mathrm{R}$ to overestimate the correlations between variables, we will consider the coefficient of determination $\mathrm{R}^{2}$.

We will further exemplify the procedure used for data processing. Firstly, we entered the data, taken from the Eurostat database, for each selected country, in SPSS. Then, we calculated the Pearson correlation coefficient and $\mathrm{R}^{2}$ for the two variables included in the research.

Table 1. Calculation of the Pearson coefficient and $\mathrm{R}^{2}$ for the variables

\begin{tabular}{lcccccc}
\hline \multirow{2}{*}{ Country } & \multicolumn{3}{c}{ Male } & \multicolumn{3}{c}{ Female } \\
\cline { 2 - 7 } & $\mathbf{R}$ & $\mathbf{R}^{2}$ & Sig. & $\mathbf{R}$ & $\mathbf{R}^{2}$ & Sig. \\
\hline Bulgaria & - & 0.672 & 0.000 & - & 0.728 & 0.000 \\
& 0.082 & & & 0.854 & & \\
Czech & 0.458 & 0.210 & 0.028 & 0.001 & $9.904 \mathrm{E}-$ & 0.498 \\
Republic & - & & & - & 7 & \\
Poland & - & 0.221 & 0.049 & 0.564 & 0.318 & 0.015 \\
& 0.470 & & & - & & \\
Romania & - & 0.596 & 0.000 & 0.780 & 0.608 & 0.000 \\
& 0.772 & 0.072 & 0.141 & 0.486 & 0.236 & 0.041 \\
Slovakia & 0.268 & 0.072 & & \\
Slovenia & - & 0.216 & 0.026 & 0.161 & 0.026 & 0.262 \\
& 0.464 & & & & & \\
Hungary & - & 0.015 & 0.314 & 0.184 & 0.034 & 0.233 \\
& 0.123 & & & & & \\
\hline
\end{tabular}

Further, we interpreted the resulting output. For the model to be accepted, we consult the Sig. value (level of significance or probability) which must be less than or equal to $0.05 \mathrm{We}$ then observe the sign of the Pearson correlation coefficient, which indicates the direction in which the variables vary, the nature of the relationship. Finally, we will appreciate how strong the correlation is. We will analyze the extent to which the variables are correlated, based on the coefficient of determination $\mathrm{R}^{2}$. The higher the value of $\mathrm{R}^{2}$, the more significant the linear regression will be considered.

After interpreting the output, we made the dispersion diagrams by placing the two variables, the level of development of countries on the $\mathrm{X}$ axis and the school dropout rate on the $\mathrm{Y}$ axis. Finally, we interpreted the resulting output. These two last steps are detailed in the next section.

\section{Empirical results}

In this research we took into account the school dropout rate relative to the level of development of the following emerging countries in Central and Eastern Europe: Romania, Hungary, Bulgaria, Slovakia, Slovenia, Poland and the Czech Republic. The variables used in the analysis is the gross domestic product, and the dropout rate, in males and females. The data used refer to the period 2002-2019 and were extracted from the European Commission's Eurostat database.

Analyzing the data collected regarding the countries included in this research, significant differences can be observed between them both in terms of school dropout rate and in terms of annual gross domestic product.

Our goal is to identify a correlation between the two variables mentioned, namely dropout rate and the level of development of a country seen in terms of gross domestic product.

The reason for choosing the countries in this research is given by the geo-political context that affected the social life of individuals. These satellite countries belonged to the communist bloc, and the late accession to the European Union is given precisely by the applied political regime. The establishment of late European norms that take into account the regulation of various aspects related to the functioning of the education system is a determining factor in the school dropout rate.

In Figure 1 we can observe the correlation between the dropout rate for females and the gross domestic product, in the countries included in our analysis. The possibility of a negative correlation between the $\mathrm{x} 1$ variable "dropout rate" found on the $\mathrm{Y}$ axis and the $\mathrm{x} 2$ variable "gross domestic product" exposed on the $\mathrm{X}$ axis is analyzed. The correlation tables obtained indicate, as can be seen below, a negative association between the two variables, with the exception of the Czech Republic, as well as in the case of Slovenia and Hungary.

Results show that in three of the seven countries included in the research, namely the Czech Republic, Slovenia and Hungary, there is no relationship between the two variables included in the analysis. In two other countries in our analysis, Poland and Slovakia, it can be seen that, although there is a correlation between the variables, it is weakly significant, the determining coefficient $\mathrm{R}^{2}$ having a value of 0.318 in the first country and 0.236 in the second country, meaning that the $x 1$ variable expresses in a proportion of only $31.8 \%$, respectively $23.6 \%$ the variation of the $\mathrm{x} 2$ variable. The most significant associations between variables are registered in Bulgaria, with $\mathrm{R}^{2}$ equal to 0.728 and Romania, where $\mathrm{R}^{2}$ is equal to 0.608 . 

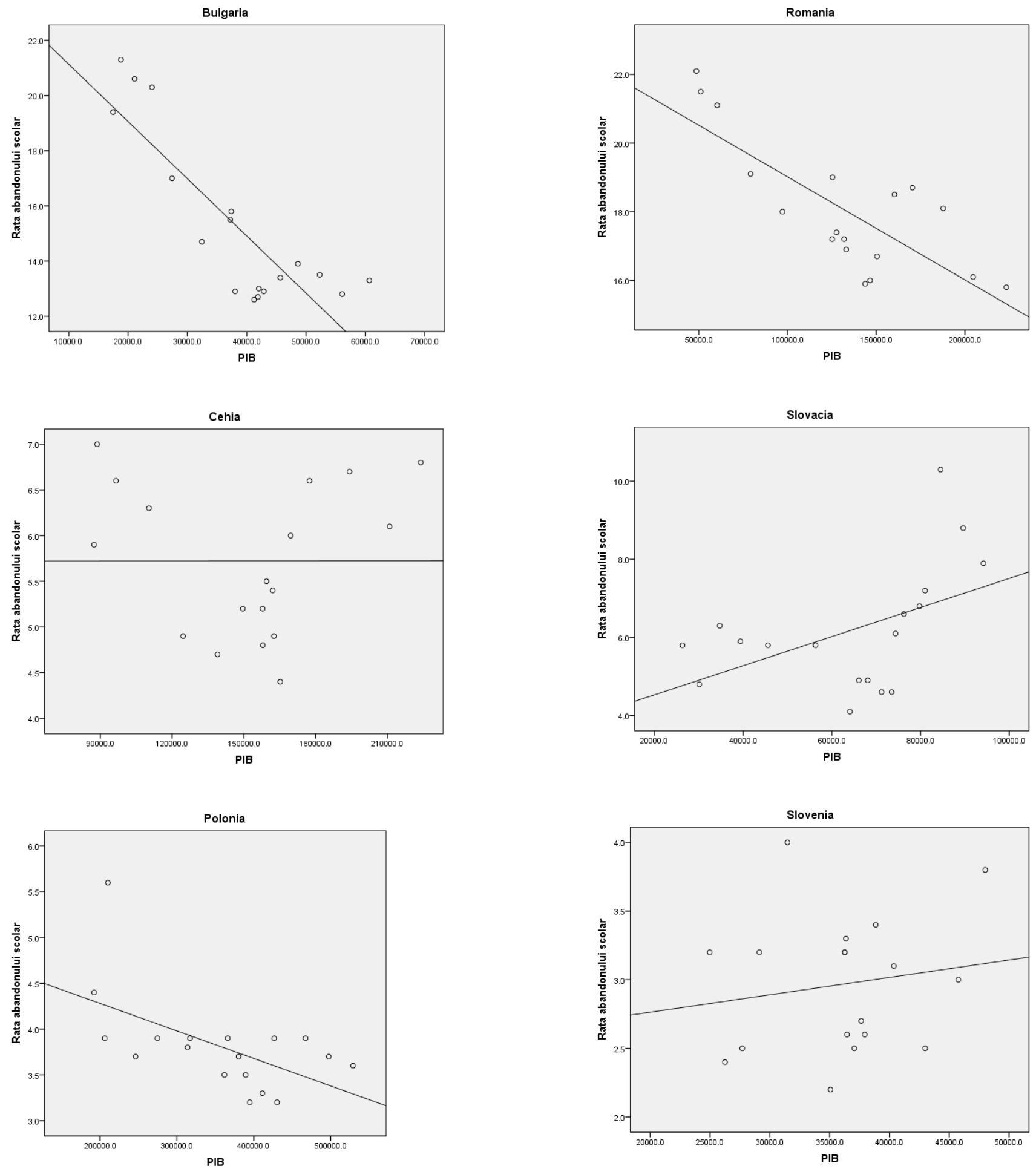


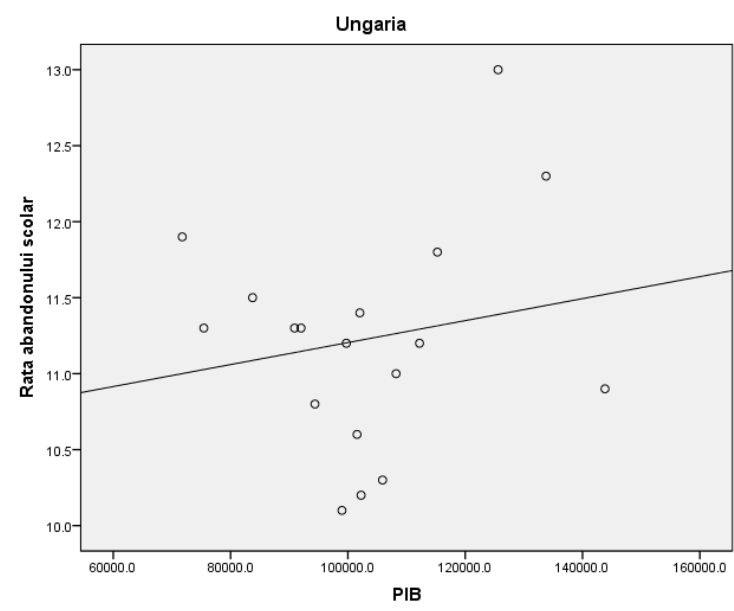

Figure 1 - Correlogram of the school dropout rate among females

Source: Processing of the author according to the information provided by the Eurostat database

In Figure 2 we can observe the correlation between the dropout rate for males and the gross domestic product, in the countries included in our analysis. The possibility of a negative correlation between the $\mathrm{x} 2$ variable "dropout rate" found on the $\mathrm{Y}$ axis and the $\mathrm{x} 1$ variable "gross domestic product" exposed on the $\mathrm{X}$ axis is analyzed. The correlation tables obtained indicate, as can be seen below, a negative association between the two variables, with the exception of the Czech Republic, as well as in the case of Slovenia, Slovakia and Hungary.

Results show that, unlike the analysis performed on females, in four of the seven countries included in the research, namely the Czech Republic, Slovakia, Slovenia and Hungary, there is no relationship between the two variables included in the analysis.

In Poland it can be seen that, although there is a correlation between the variables, it is weakly significant, the determining coefficient $\mathrm{R}^{2}$ having a value of 0.221 , meaning that the $\mathrm{x} 1$ variable expresses in a proportion of only $22.1 \%$ the variation of the $\mathrm{x} 2$ variable. The most significant associations between variables are registered in Bulgaria, with $\mathrm{R}^{2}$ equal to 0.672 and Romania, where $\mathrm{R}^{2}$ is equal to 0.596 .

The results obtained can be explained by the fact that an increase in a country's gross domestic product leads to a greater capacity for state investment in key areas, including education. Thus, through the financial support provided by the state, there is the possibility of solving certain problems, both of the school, such as supplies provided to children, auxiliary materials needed in the teaching-learning process, technological equipment, and the community, such as financial support for families facing financial problems or psychological counselling for children in situations that may make it difficult to continue the learning process, problems which determine the appearance of the school dropout phenomenon.
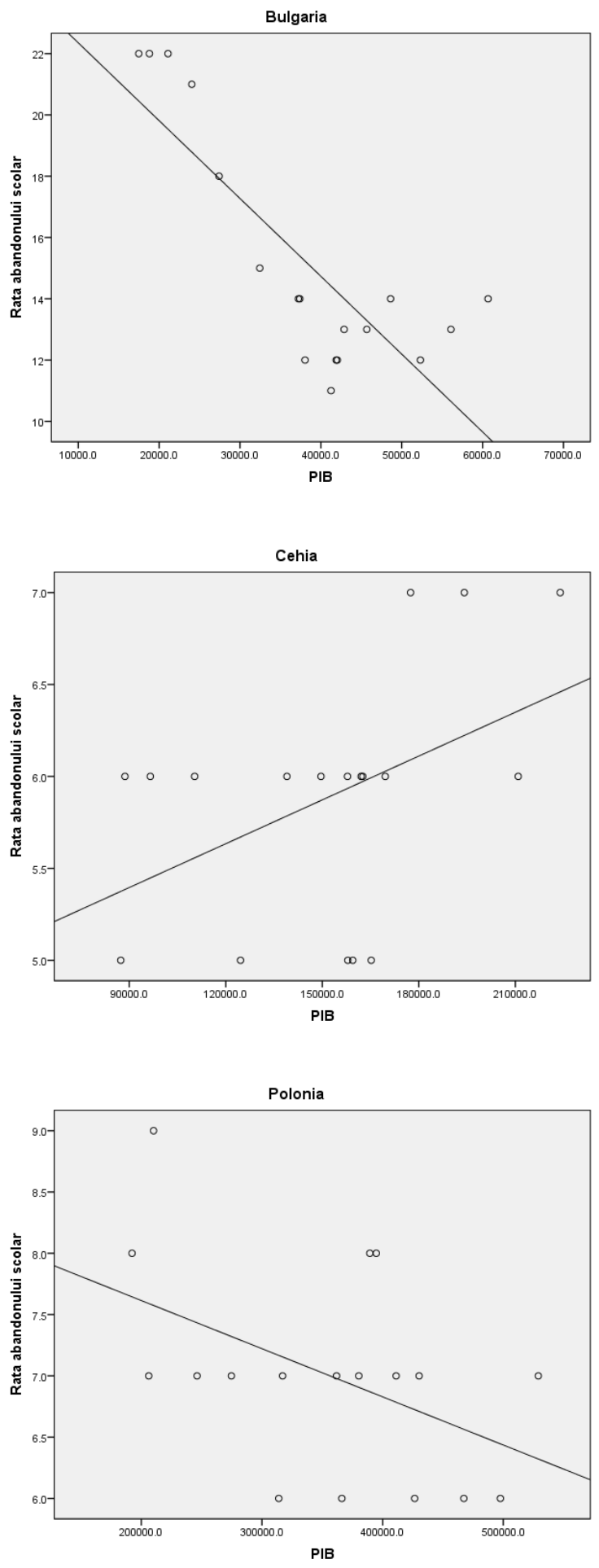

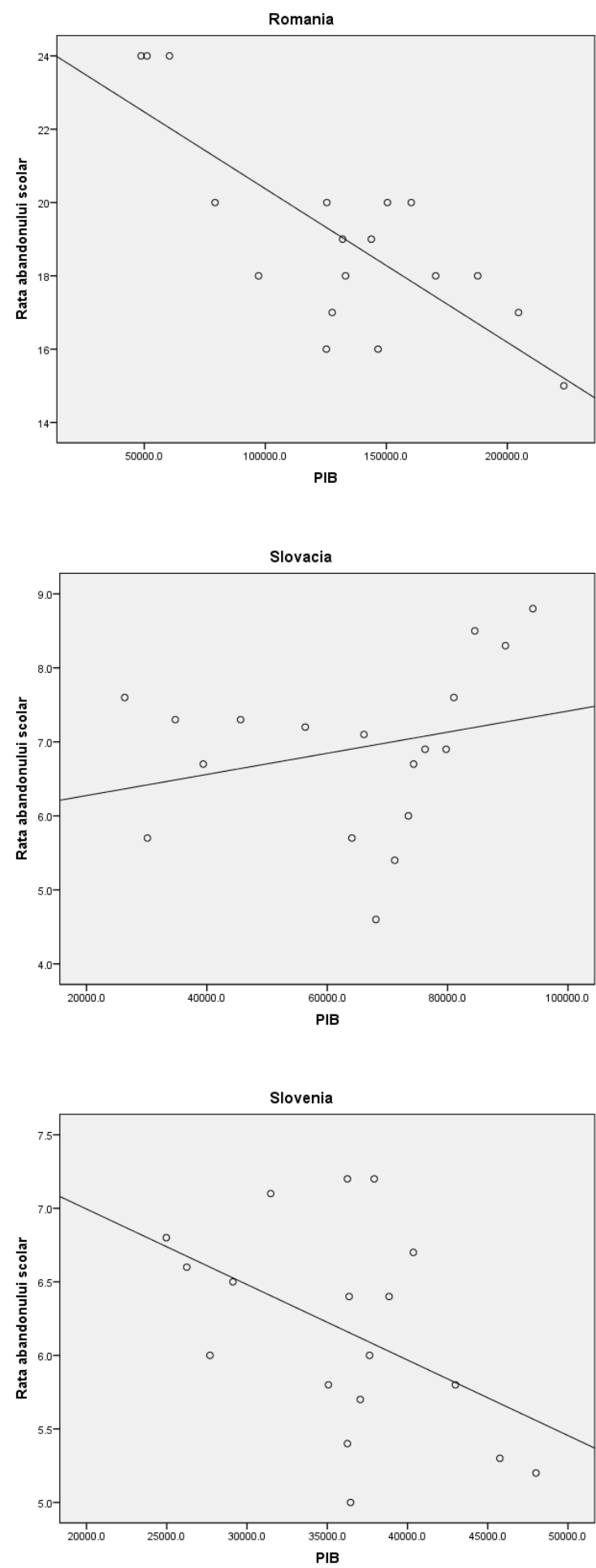

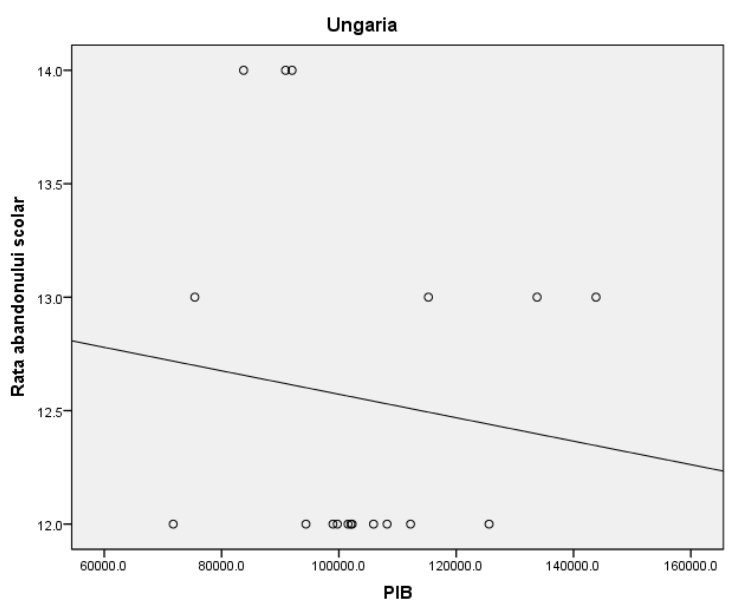

Figure 2. Correlogram of the school dropout rate among males

Source: Processing of the author according to the information provided by the Eurostat database.

\section{Conclusions and discussions}

Following this research on the correlation between the dropout rate and the level of development of emerging countries in Central and Eastern Europe we can conclude that the first hypothesis, which states that there is a significant negative correlation between the dropout rate in males and the level of the development of emerging countries in Central and Eastern Europe, is refuted, because in four of the seven countries involved in the study there are insignificant or weakly significant correlations between the variables involved in the analysis. Unlike the first hypothesis, the second hypothesis, which states that there is a significant negative correlation between the dropout rate for females and the level of development of emerging countries in Central and Eastern Europe, is confirmed, because there are significant and strongly significant correlations in four of the seven countries included in the analysis.

This research has its practical applicability through the potential to identify, based on the results, some factors that influence school dropout nationally or at the level of other countries, as well as to identify possible solutions to improve the dropout rate. Although various solutions or ways have been identified over time to prevent and reduce the number of students leaving school, they have proved their effectiveness to a small extent precisely through the results obtained, namely an increased school dropout rate. This is a phenomenon that is intended to be eliminated as much as possible because it causes adverse effects, from the individual level to society. Among the best known effects of dropping out of school is the inability of the individual to integrate into the labour market that causes individual financial problems, but this phenomenon can also create negative effects at the psychological level. 
Regarding barriers to research, we identified access to real school dropout data, which may be limited for fear of the individual being judged, the school, and the community of being in an unfavourable light by comparison with other schools or communities. This is explained by the fact that any human being tends towards success, towards personal and professional achievement, at a certain level, depending on abilities. School dropout indicates, to a certain extent, an inability of the individual to achieve that level of success proposed voluntarily or involuntarily. School dropout comes, at the same time, with a stigma from the entourage or society, and for this reason the individual tends to hide or avoid this subject.

Due to the small volume of information in the literature regarding the correlation between the level of development of emerging countries and the school dropout rate, we consider that the contribution of this paper is considerable in this regard and can be the basis for future research through the results.

\section{Authors note:}

Vodă Ioana-Maria is a student at the "Lucian Blaga" University of Sibiu, Faculty of Economic Sciences, specialization in Accounting and Management Informatics. She graduated from the Faculty of Psychology and Educational Sciences, specialization in Psychology, at the "Dimitrie Cantemir" University of Târgu Mureș, and has a master's degree in Forensic Psychology and Criminology, Evaluation and Intervention from the "Lucian Blaga" University of Sibiu, Faculty of Socio-Human Sciences. Her research interests focus on psychology and educational field. She currently serves as a teacher for primary education at "Miron Cristea" Secondary School from Toplița, Harghita county.

\section{References}

Andrei, T., Teodorescu, D., Oancea, B. (2011). Characteristics and causes of school dropout in the countries of the European Union. Procedia-Social and Behavioural Sciences, 28, 328-332.

Apostu, O., Balica, M., Fartușnic, C., Florian, B., Horga, I., Novak, C., Voinea, L. (2015). Analiza sistemului de invățământ preuniversitar din România din perspectiva unor indicatori statistici. Politici educaționale bazate pe date. Bucharest: University Publishing House.

Cosmovici, A., Iacob, L. (1999). Psihologie școlară. Iași: Polirom Publishing House.

Doron, R., Parot, F. (2006). Dicționar de psihologie. Bucharest: Humanitas Publishing House.

Gyonos, E. (2011). Abandonul școlar: cauze și efecte. Economie teoretică și aplicată,Volume XVIII, no. 11 (564), 37-47.

Howitt, D., Cramer, D. (2010). Introducere in SPSS pentru psihologie. Iași: Polirom Publishing House.

Jigău, M., Fartușnic, C., Apostu, O., Baliza, M., Florian, B., Horga, I., Voinea, L. (2011). Estimarea dimensiunii fenomenului de abandon şcolar folosind metodologia analizei pe cohortă. Bucharest: ISE.

Vasile, M. (2014). Introducere în SPSS pentru cercetarea socială și de piață. Iași: Polirom Publishing House.

Vîrlan, M., Dița, M. (2018). Diminuarea abandonului școlar prin activități psiho-socio-educative. Journal of Psychology. Special Pedagogy. Social Work, e-ISSN: 1857-4432, Volume 20, no.1, 43-55.

European Commission, Eurostat, Early leavers from education and training by sex and labour status,https://appsso.eurostat.ec.europa.eu/nui/show.d $o$ ?dataset=edat_lfse_14\&lang=en (Accessed at 29.09. 2020).

European Commission, Eurostat, GDP and main components (output, expenditure and income), https://appsso.eurostat.ec.europa.eu/nui/show.do?datase $t=$ nama_10_gdp\&lang=en (Accessed at 29.09. 2020). 